\title{
The Development of Microcredit in China under the Microfinance
}

\author{
Zining Zhen \\ China Foreign Economy and Trade Trust Co., LTD, Beijing, China \\ Email: ziningzhen@126.com
}

How to cite this paper: Zhen, Z.N. (2019) The Development of Microcredit in China under the Microfinance. American Journal of Industrial and Business Management, 9, 1486-1491.

https://doi.org/10.4236/ajibm.2019.96098

Received: May 7, 2019

Accepted: June 27, 2019

Published: June 30, 2019

Copyright $\odot 2019$ by author(s) and Scientific Research Publishing Inc. This work is licensed under the Creative Commons Attribution International License (CC BY 4.0).

http://creativecommons.org/licenses/by/4.0/

\begin{abstract}
Since 2008 a series of financial policies have been introduced, microfinance development has entered a new stage. As a branch of microfinance, microcredit also ushered in a significant opportunity for rapid development. Commercial Banks, microcredit companies and other financial institutions have launched microcredit products for small and micro businesses and individuals. After a period of practice, there are a lot of problems remain to be solved. By analyzing the development stage of microcredit in China, this paper explores the existing problems in the development of microcredit in China and puts forward relevant suggestions on the premise of distinguishing the concepts of microfinance and microcredit.
\end{abstract}

\section{Keywords}

Microfinance, Microcredit, Policy Suggestions

\section{Introduction}

From 2005 to 2018, Chinese government and regulatory authorities strongly supported the development of microfinance business, regional small and medium-sized banks. On one hand, the domestic microfinance business was facing an important opportunity and receiving a lot of attention from the whole society; on the other hand, microfinance business development is limited by various aspects. However, in the favorable policy situation, Chinese microcredit business will enter a stage of rapid development.

\section{Concept}

Microfinance refers to a series of financial services such as loans, savings, remittances, insurance and currency payment, etc. that particularly provided to low-income families and small and microenterprises [1]. 
Microcredit is a type of "microfinance" and mainly focuses on the microfinance activities for the rural people with low-income.

\section{Stages of Development}

In 1993, Chinese Academy of Social Sciences copied and carried out the experimental model of microcredit of Grameen bank of Bangladesh, which started the microcredit activities in China. Up to now, microcredit service has existed for 26 years in Chinese financial market and can be divided into three following stages:

\subsection{First Stage (1994-1998)}

This stage was the experimental stage. International institutions such as the United Nations development fund for women, Hong Kong Oxford and etc. began to provide various assistance programs to China through microcredit from the 1980s. And the poverty alleviation program launched by the Chinese academy of social sciences in four project experimental sites in 1993 marked the official launch of China's microcredit activities.

Funded by Ford Foundation, Grameen Trust and Canadian Funds, China's first poverty relief agencies, namely the cooperatives for poverty alleviation which adopting Grameen bank's microcredit experimental model (GB model for short) was established by the rural development institute of Chinese Academy of Social Sciences in Hebei Yixian county in 1994, Ever since, the microcredit business was conducted as an independent financial service in China [2].

Based on previous experience of Yixian county, the United Nations Development Programme (UNDP) carried out a series of projects of microcredit in 1995 in 48 counties of 17 provinces and four large and medium-sized cities like Tianjin in China. This is one of the largest microcredit projects in China assisted by international organizations.

In September 1996, sponsored by the UNDP, the World Bank and the Ford Foundation, rural development institute of Chinese Academy of Social Sciences held an international seminar on "Microcredit for poverty alleviation" in Beijing which turned out to be a great success. Participants reached a consensus on the positive role microcredit played in poverty alleviation, and later on, poverty alleviation work using microcredit set off the first climax in China.

In 1998, the Poverty Relief Office of the State Council clearly put forward "microcredit" as the main form of financial poverty alleviation loans at the national poverty alleviation work conference.

\subsection{Second Stage (1999-2004)}

The second stage can be considered as a stage for the full participation of government financial institutions and the institutionalization of various projects. In 1999, rural credit cooperatives began to offer microcredit and group loans to rural households. It was the first government bank in China to offer microcredit to farmers. Under the supervision of The People's Bank of China (PBOC), Rural 
Credit Cooperatives (RCCs), spreading throughout the country's villages and towns, have become the largest microcredit practitioners in China.

With the transformation of economic development and the upgrading of industrial structure, a large number of laid-off workers are faced with the difficulties of re-employment. To meet their financial needs, since 2002, the central government has encouraged local and provincial governments to establish re-employment guarantee funds to help laid-off workers to maintain self-employment with these funds. As a result, the microcredit market has spread from rural to cities.

\subsection{Third Stage (Since 2005)}

This stage marks the standardization and institutionalization of microcredit. In 2005 cooperating with rural credit cooperatives, The People's Bank of China invested or opened microcredit companies in the province of Sichuan, Guizhou, Shanxi, Shaanxi and Inner Mongolia and the number of which reached 8,133 with the credit scale of 95 billion yuan. The rapid development of microcredit companies was very important to financial poverty alleviation [3].

Since 2010, The People's Bank of China, China banking regulatory commission and other regulatory authorities have formulated relevant policies and documents in support of microcredit on a very frequent basis. In such circumstances, with the support of local governments, the microcredit in China has experienced rapid development and it gradually grew into a multi-level and pluralistic market pattern with commercial Banks, rural commercial banks and rural credit cooperatives as the dominated power and new type of rural financial institutions and microcredit companies as the supplementary to provide service mainly to small businesses, the micro enterprises and individual enterprises and farmers, etc.

By the end of 2018, the balance of the inclusive finance loans was 13.39 trillion yuan, $13.8 \%$ year-on-year growth and 5.3\% higher than that at the end of last year. For the whole year, it increased by 1.62 trillion yuan, an increase of 695.8 billion yuan over the previous year ${ }^{1}$.

\section{Problems of the Development of Microcredit in China}

Microcredit has proven positive effects in upgrading agricultural industry structure, diversifying of financial institutions, and meeting the loan demand of middle-and low-income groups. However, there still some problems remain.

\subsection{Imbalance between Supply and Demand}

Main customer group of microcredit business consists of micro enterprises, urban entrepreneurs, self-employed, re-employment personnel, a large number of migrant workers and, farmers whose main source of income is from agricultural production. The loan demand of them usually has the following characteristics: small amount, high frequency and urgency, high risk and low return which re${ }^{1}$ http://www.pbc.gov.cn/ 
sult, in high costs of pre-lending review and post-loan monitoring, high risk and low willingness for financial institutions who focuses on safety, efficiency and liquidity in daily financial operations.

\subsection{Risk Prevention Mechanism Is Not Sound}

Microcredit has been applied as a rural poverty alleviation pilot project with the purpose of supporting the poor population and developing the economy since it was introduced to China. However, it has not established a sound credit system which leads to a slow development for several reasons.

First, main clients of microcredit are small-and-micro businesses and farmers whose mortgage property lacks of high quality and credit record. What's more, microcredit is often unsecured, which leads to a high risk for the institutions.

In addition, the microcredit system in China is modified from the GB bank in Bangladesh whose core lies in the regular repayment position and the group center meeting system to control risks. However in China's case, it demands the lender to pay off the load within the agreement tenancy at one time, so the group center meeting system cannot be effectively implemented, and the mutual protection function is also missing which increase the credit risks.

\subsection{Small-and-Micro Enterprises Bear Higher Loan Costs}

Due to the dispersion of position distribution and small business volumes, the small-and-micro businesses, as estimated, own five times of the average management cost of commercial Banks for loans than large enterprises. As a result, it is difficult for many branch institutions to profit in a short term. Moreover, Microcredit is often with smaller amount and shorter loan terms which lead to greater workload and higher operation costs. And mortgages with low qualities usually result in high loan interest rate or credit loans which increase the financing costs [4].

\subsection{The Non-Performing Rate of Agriculture Loans Is High}

In China, microcredit is largely applied to poverty alleviation in rural areas and has a high non-performing loan rate. At the end of 2018, the non-performing loan balance of rural commercial bank was 535.4 billion yuan, and the non-performing loan ratio was $3.96 \%$. In the same period, commercial Banks' non-performing loans reached 2.03 trillion yuan, with a non-performing loan ratio of $1.83 \%$. The non-performing loan ratio of rural commercial bank is much higher than that of commercial bank ${ }^{2}$.

\section{Policy Suggestions}

\subsection{Policy Supports}

Referring to foreign experience, the governments should provide more favorable tax and exemption policies to reduce taxes and interest rates, to improve capital ${ }^{2}$ http://www.circ.gov.cn 
usage, to adopt differentiated long-term preferential measures and to lower the threshold limit of interbank lending market. Moreover, preferential treatment in terms of business tax and income tax should be given to financial institutions with good performance on and microcredit to increase their enthusiasm of microcredit business.

At the same time, private capital and foreign institutions should be encouraged, to create a moderate competition in the financial environment, and to build a diversified microcredit organizational system.

\subsection{Credit Guarantee System}

Financial institutions should establish diversified pricing system based on customers' credits rather than complete on the collateral, and improve the proportion of co-insurance, mutual insurance and credit loans to strengthen the innovation of financial products, and improve risk control and hedging ability.

At the same time, the governments should complete the credit information system of enterprises and individuals, and build credit investigation platforms to disclose credit records of enterprises and individuals legally to facilitate financial institutions' dynamic monitoring of small-and-micro enterprises and farmers' credit status.

\subsection{Credit Rating Mechanism}

It is very important for financial institutions to accurately assess credit risks of small-and-micro enterprises and farmers to maintain safe financial operation. The establishment and improvement of a credit rating system can reduce the management cost and credit risk of financial institutions.

Drawing on the experience of international and professional institutions, scientific assessment methods should be adopted to objectively evaluate the credits of small-and-micro enterprises and farmers, and these data could be used for credit inquiry. At the same time, it is very important to build an honest investment environment by improving the popularization of microcredit knowledge, the credit awareness of the market entities and the quality of microcredit practitioners through frequent, standardized and systematic compliance education.

\section{Conflicts of Interest}

The authors declare no conflicts of interest regarding the publication of this paper.

\section{References}

[1] $\mathrm{Hu}, \mathrm{B}$. and Wang, J.L. (2010) Mature Industry, Alternative Investment-The Burgeoning International Microfinance Industry and Microfinance Investment. Financial Development Review, 2010, 37-49.

[2] Du, X.S. (2004) China's Rural Microfinance Practice Attempt. China Rural Econo$m y, 2004,12-19+30$. 
[3] Du, X.S. and Sun, R.M. (2000) Practice and Policy Thinking of Microfinance in China. Finance \& Trade Economics, 2002, 32-37.

[4] Chen, P. (2007) International Microfinance and China's Rural Financial Reform -Based on the International Perspective and Guizhou's Practice. Financial Theory \& Practice, 2007, 24-26. 